\title{
PENGEMBANGAN MEDIA PEMBELAJARAN PENGENDALI KECEPATAN DAN SOFT STARTING MOTOR LISTRIK BERBASIS ARDUINO PADA MATA KULIAH PENGGUNAAN DAN PENGATURAN MOTOR
}

\author{
Cahya Alim Wijaya ${ }^{1}$, Jeffry Handhika ${ }^{2}$, Sulistyaning Kartikawati ${ }^{3}$ \\ ${ }^{1,3}$ Pendidikan Teknik Elektro, Universitas PGRI Madiun \\ Madiun, 63118, Indonesia \\ ${ }^{2}$ Pendidikan Fisika, FKIP, Universitas PGRI Madiun \\ Madiun, 63118, Indonesia \\ Email:cahyaaw26@gmail.com¹; jhandika@unipma.ac.id² \\ sulistyaningk@gmail.com ${ }^{3}$
}

\begin{abstract}
Abstrak.Penelitian ini bertujuan untuk mengetahuimengetahui tingkat kelayakan trainer pengendali kecepatan dan soft starting motor listrik sebagai media pembelajaran. Dalam pembelajaran mata kuliah penggunaan dan pengaturan motor kurang adaya kolaborasi penggunaan media pembelajaran yang efisien, membuat mahasiswa kurang aktif dalam pembelajaran dan minat belajar mahasiswa menjadi kurang.

Penelitian ini merupakan penelitian Research and Development $(R \& D)$ dengan metode ADDIE yang meliputi: (1) Analysis (Analisis), (2) Design (Desain), (3) Development (Pengembangan), (4) Implementation (Implementasi), (5) Evaluation (Evaluasi). Penelitian ini dilakukan di Program Studi Pendidikan Teknik Elektro Universitas PGRI Madiun. Subyek penelitian adalah satu kelas mahasiswa semester 6 yang berjumlah 13 orang dan obyek penelitian adalah media pembelajaran pengendali kecepatan dan soft starting motor listrik. Instrumen yang digunakan adalah wawancara dan angket dengan lima pilihan jawaban untuk ahli media dan mahasiswa. Media pembelajaran ini divalidasi oleh 2 ahli media pembelajaran.

Berdasarkan hasil unjuk kerja dari trainer diketahui bahwa rangkaian yang ada dapat bekerja dengan baik. Sedangkan hasil kelayakan media pembelajaran ditinjau dari ahli media mendapatkan skor persentase 83,22\% dan dikategorikan "sangat layak". Uji pemakaian dinilai berdasarkan angket yang di isi oleh 13 orang mahasiswa dan hasil dari uji pemakaian ini mendapatkan skor $82,10 \%$ dan dikategorikan "sangat layak".
\end{abstract}

Kata kunci: Media Pembelajaran, Motor Listrik, Arduino

\section{Pendahuluan}

Pendidikan merupakan sebuah sarana yang efektif dalam mendukung perkembangan serta peningkatan sumber daya manusia menuju ke arah yang positif. Kemajuan suatu bangsa bergantung kepada sumber daya manusia yang berkualitas, dimana hal itu sangat ditentukan dengan adanya pendidikan. Seperti yang tertulis dalam Undang-undang nomor 20 tahun 2003 tentang Sistem Pendidikan Nasional, yang salah satu isinya membahas mengenai pendidikan adalah usaha sadar dan terencana untuk mewujudkan suasana belajar dan proses pembelajaran agar peserta didik secara aktif mengembangkan potensi dirinya untuk memiliki kekuatan spiritual keagamaan, pengendalian diri, kepribadian, kecerdasan, akhlak mulia serta ketrampilan yang diperlukan dirinya, masyarakat bangsa dan negara.

Pengenalan teknologi baru harus dilakukan dalam proses belajar mengajar agar peserta didik siap dalam menghadapi tantangan dunia di era teknologi. Kualitas belajar mengajar akan sangat berpengaruh terhadap hasil belajar. Salah satu yang mendukung terhadap kualitas belajar adalah ketersediaan media pembelajaran. 
Media pembelajaran merupakan alat bantu dalam pembelajaran untuk menyampaikan materi pembelajaran dari guru kepada siswa agar informasi yang disampaikan dapat lebih mudah dipahami. Menurut Arsyad (2011: 16), Fungsi media pembelajaran juga dapat membantu siswa meningkatkan pemahaman, menyajikan data dengan menarik dan terpercaya, memudahkan penafsiran data, dan memadatkan informasi.

Perkuliahan Program Studi Pendidikan Teknik Elektro adalah salah satu sasaran yang paling baik dalam pengembangan media pembelajaran. Dari hasil pengamatan peneliti selama perkuliahan dalam program mata kuliah penggunaan dan pengaturan motor, mahasiswa menggunakan berbagai media pembelajaran pengasutan motor. Namun media pembelajaran tersebut masih berupa power point atau hanya sebatas materi saja dan belum adanya bentuk nyata dari alat pengasutan motor yang telah dibahas. Penggunaan media pembelajaran tersebut memang telah mendukung dalam proses perkuliahan, namun dalam rangka menanggapi tuntutan teknologi maka diperlukan perkembangan dalam materi maupun media penunjang perkuliahan agar mahasiswa lebih kompeten dalam belajar. Tidak berkembangnya media pembelajaran yang membahas tentang pengasutan motor yang ada pada mata kuliah penggunaan dan pengaturan motor mengakibatkan mahasiswa buta dalam perkembangan teknologi. Kurangnya sarana alat bantu yang disediakan oleh laboratorium Program Studi Pendidikan Teknik Elektro Universitas PGRI Madiun menjadi salah satu rendahnya minat belajar mahasiswa. Sehingga peneliti memilih pengasut soft starter yang telah diterapkan dalam dunia industri, menjadi salah satu trainermedia pembelajaran bagi mahasiswa Program Studi Pendidikan Teknik Elektro Fakultas Keguruan dan Ilmu Pendidikan Universitas PGRI Madiun agar dapat berkembang memenuhi tuntutan dunia industri. Alasan peneliti memilih pengasut soft starter adalah karena rangkaiannya yang sederhana serta murah dalam pembuatannya.

Dari dasar uraian permasalahan diatas, peneliti bermaksud untuk melakukan penelitian dengan judul: "Pengembangan Media Pembelajaran Pengendali Kecepatan dan Soft Starting Motor Berbasis ArduinoPada Mata Kuliah Penggunaan dan Pengaturan Motor".Penelitian ini bertujuan untuk mengembangkandan mengetahui tingkan kelayakan media pembelajaran pengendali kecepatan dan soft starting motor listrik berbasis arduino pada mata kuliah penggunaan dan pengaturan motor.

\section{Metode Penelitian}

Penelitian pengembangan media pembelajaran pengendali kecepatan dan soft starting motor ini termasuk dalam metode Penelitian dan Pengembangan (research and development) dalam bidang pendidikan.Model yang digunakan dalam penelitian ini adalah ADDIE menurut Branch (dalam Rizky, 2016: 63) merupakan singkatan dari Analysis, Design,Development, Implementation, dan Evaluation (ADDIE). Perancangan media ini meliputi beberapa tahap, yaitu: (1) analisis kebutuhan, (2) desain, (3) pengembangan produk, (4) Implementasi atau uji coba pemakaian, (5) evaluasi (revisi).Pelaksanaan penelitian ini dilakukan secara bertahap dan sesuai dengan tahapan-tahapan penelitian yang telah disusun.Adapun tahap-tahap pelaksanaannya sebagai berikut:

a. Tahap Eksplorasi, meliputi: (1) tempat dan waktu eksplorasi, (2) metode eksplorasi, (3) sumber data eksplorasi, (4) teknik pengumpulan data, (5) teknik analisis data, (6) output tahap eksplorasi. 
b. Tahap pengembangan, meliputi: (1) tempat dan waktu pengembangan, (2) mekanisme pengembangan, (3) teknik pengumpulan data, (4) teknik analisis data, (5) output tahap pengembangan.

Dalam penelitian ini menggunakan instrumen wawancara dan angket. Wawancara dilakukan untuk menganalisis mengenai media pembelajaran yang dibutuhkan untuk dilakukannya pengembangan, sedangkan angket digunakan untuk menilai tingkat kelayakan media pembelajaran yang dikembangkan. Responden dalam penelitian yakni ahli media dan mahasiswa yang bertindak sebagai pengguna. Angket yang telah terkumpul dihitung berdasarkan sistem penilaian yang telah ditetapkan.

Teknik analisis data yang dilakukan pada tahap eksplorasi adalah menggunakan deskriptif kualitatif, yakni memaparkan rancangan media pembelajaran. Tahap pengembangan menggunakan statistik deskriptif, yakni memaparkan hasil penilaian dosen ahli media dan mahasiswa mengenai kelayakan produk ketika diimplementasikan.

Berdasarkan data instrumen penelitian kemudian dilihat bobot tiap pertanyaan, selanjutnya menghitung skor rata-rata hasil penilaian tiap komponen media pembelajaran pengendali kecepatan dan soft starting motor listrik dan menghitung persentase skor kelayakan. Selanjutnya, kategori kelayakan digolongkan menggunakan skala berikut:

\begin{tabular}{lc}
\multicolumn{1}{c}{ Tabel 1. Kategori kelayakan media pembelajaran } \\
\hline Kategori kelayakan & Hasil ranting \\
\hline Sangat layak & $81-100$ \\
\hline Layak & $61-80$ \\
\hline Cukup layak & $41-60$ \\
\hline Kurang layak & $21-40$ \\
\hline Tidak layak & $0-20$ \\
\hline
\end{tabular}

\section{Hasil Penelitian dan Pembahasan}

Media pembelajaran yang dikembangkan berupa trainer pada mata kuliah penggunaan dan pengaturan motor, trainer dapat digunakan mahasiswa untuk belajar mengenai pengaturan motor secara mandiri maupun bersama-sama. Prosedur penelitian dan pengembangan yang digunakan adalah sesuai dengan buku pedoman skripsi Universitas PGRI Madiun Tahun 2017, sedangkan model pengembangan yang digunakan mengadaptasi model prosedur ADDIE. Model pengembangan ADDIE diawali dengan tahap Analysis, Design, Development, Implementation, dan Evaluation. Hasil dari penelitian pengembangan adalah produk trainer yang layak digunakan pada mata kuliah penggunaan dan pengaturan motor.

Trainer atau alat peraga dapat memudahkan mahasiswa dalam memahami sebuah materi perkuliahan, meningkatkan motivasi, dan meningkatkan perhatian. Hal ini sejalan dengan penelitian yang dilakukan olehSetyowati dkk (2016: 30) bahwa penggunaan alat peraga ternyata menjadi daya tarik sendiri bagi siswa karena pembelajaran menjadi lebih bervariasi, tidak monoton dan melibatkan peran aktif siswa. Dengan demikian siswa menjadi lebih mudah memahami materi dan akhirnya hasil belajar yang diperoleh meningkat.

Analisis kelayakan bahan ajar modul diperoleh dari hasil validasi ahli media dan penilaian oleh mahasiswa. Berikut dijelaskan pembahasan analisis kelayakan media pembelajaran pengendali kecepatan dan soft starting motor listrik: 
a. Analisis Kelayakan Media Oleh Ahli Pada Tahap Uji Coba

Pengujian pertama dilakuakn oleh ahli media pembelajaran guna menguji kelayakan trainer. Aspek yang dinilai meliputi aspek tampilan, aspek teknis, dan aspek kemanfaatan. Berdasarkan penilaian yang dilakukan, media pembelajaran pengendali kecepatan dan soft starting motor ini mendapatkan skor rata-rata total dengan nilai persentase sebesar70,00\% dan masuk dalam kategori "layak". Secara keseluruhan media pembelajaran pengendali kecepatan dan soft starting motor listrik dapat diterima dan dinilai layak untuk uji pemakaian dengan sebelumnya melalui perbaikan atau revisi.

b. Analisis Kelayakan Media Oleh Mahasiswa Tahap Uji Coba

Uji coba produk dilakukan dalam lingkup skala kecil pada lima orang mahasiswa, berdasarkan hasil uji coba produk media pembelajaran pengendali kecepatan dan soft starting motor listrik mendapat total skor keseluruhan sebesar $\mathbf{6 7 , 1 0 \%}$. Nilai tersebut termasuk dalam kagori "layak". Hal ini berarti media yang digunakan mendapat respon baik oleh mahasiswa dan layak digunakan dengan perbaikan.

c. Analisis Kelayakan Uji Pemakaian Oleh Ahli

Uji pemakian dilakukan setelah produk direvisi dari penilaian uji coba produk, peneliti melakukan revisi sesusai dengan saran dan komentar ahli media. uji pemakaian ini dibagi menjadi tiga aspek yaitu aspek tampilan, teknis, dan manfaat. Berdasarkan hasil penelitian perolehan aspek tampilan sebesar $\mathbf{8 4 , 0 0 \%}$, aspek teknis 81,33\%, dan aspek manfaat meperoleh $\mathbf{8 4 , 0 0 \%}$. Dari ketiga aspek tersebut, jika dihitung rata-rata maka akan mendapatkan hasil sebesar83,22\% dan masuk dalam kategori "sangat layak" digunakan. Berdasarkan seluruh penilaian tersebut, maka dapat dikatakan bahwa media pembelajaran pengendali kecepatan dan soft starting motor listrik masuk pada kriteria kelayakan bahan ajar dengan kategori sangat layak, setelah dilakukan perbaikan.

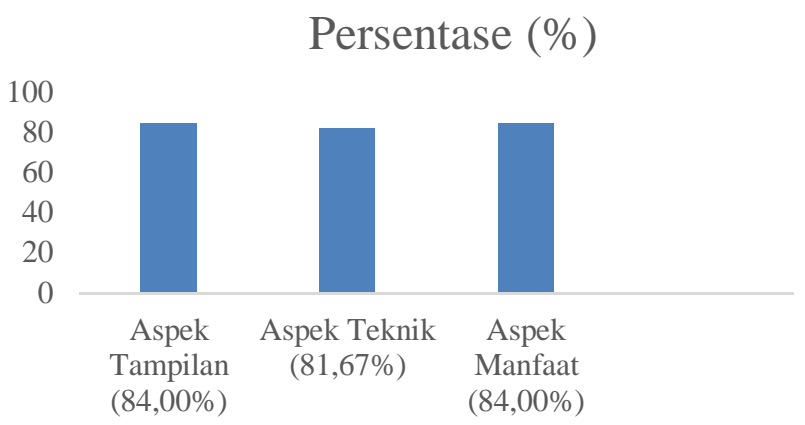

Grafik 1. Persentase uji pemakaian oleh ahli media

d. Analisis Uji Pemakaian Oleh Mahasiswa

Tingkat peneliaian yang diperoleh dari hasil uji pemakaian media pembelajaran oleh mahasiswa yang dilaksakana kepada 13 orang mahasiswa, Program Studi Pendidikan Teknik Elektro semester 6 Universistas PGRI Madiun, di tinjau dari aspek tampilan sebesar 78,15\%, sedangkan untuk aspek teknis persentase yang didapat adalah $\mathbf{8 0 , 2 6 \%}$, persentase untuk aspek materi adalah sebesar $\mathbf{8 3 , 8 5 \%}$, dan ditinjau dari 
apsek manfaat persentase yang didapat adalah sebesar 86,15\%, dengan demikian persentase kelayakan yang di dapat jika dilihat dari keseluruhan aspek, maka hasil persentase kelayakan media setelah di rata-rata adalah sebesar $\mathbf{8 2 , 1 0 \%}$. Nilai tersebut dalam kategori "sangat layak". Hal ini menyakatan bahwa media pembelajaran pengendali kecepatan dan soft starting motor listrik direspon sangat baik dan sangat layak digunakan dalam perkuliahan.

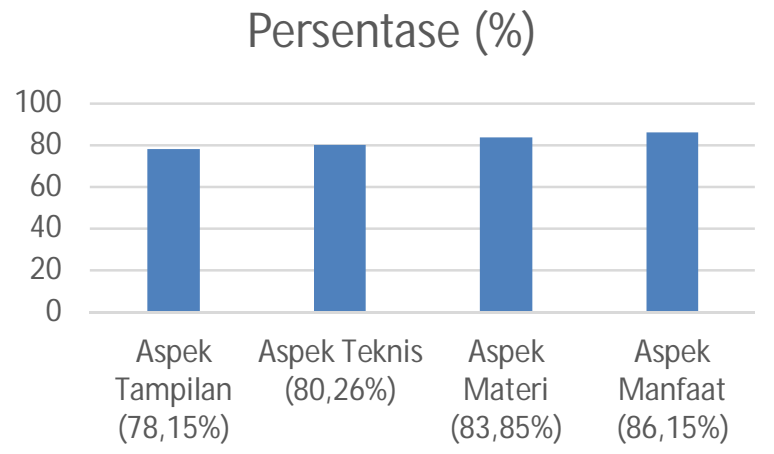

Grafik 2. Persentase uji pemakaian oleh mahasiswa

\section{Kesimpulan dan Saran}

Realisasi pengembangan media pembelajaran pengendali kecepatan dan soft starting motor listrik tersusun dari perangkat arduino uno sebagai otak pemproses pergerakan kecepatan motor apakah berjalan pada kecepatan yang diinginkan atau tidak, sensor arus sebagai pendeteksi arus, zero crossing sebagai titik persimpangan antara gelombang ac dengan titik nol, LCD 16x2 sebagai penampil data keluaran sensor arus, potensiometer sebagai pengatur kecepatan motor.

Tingkat kelayakan pengendali kecepatan dan soft starting motor listrik sebagai media pembelajaran dengan hasil uji validasi pemakaian oleh ahli media memperoleh persentase $\mathbf{8 3 , 2 2 \%}$ sehingga dikategorikan sangat layak. Untuk uji pemakaian kepada mahasiswa persentase yang di dapatkan sebesar $\mathbf{8 2 , 1 0 \%}$ sehingga dikatagorikan sangat layak.

Berdasarkan hasil penelitian yang telah diuraikan di atas, ada beberapa hal yang dapat disarankan oleh peneliti demi meningkatkan pembelajaran. Diharapkan hasil penelitian ini dapat ditindak lanjuti oleh pihak yang bersangkutan, yaitu : 1) Untuk Mahasiswa: Mahasiswa diharapakan mampu memanfaatkan media pembelajaran trainer kecepatan dan soft starting motor listrik sebagai sumber belajar yang dapat digunakan untuk belajar. 2) Untuk Program Studi Pendidikan Teknik Elektro: Program Studi Pendidikan Teknik Elektro perlu untuk meningkatkan kompetensi mahasiswa dengan mengikuti arah perkembangan teknologi terbaru. Tanpa melakukan pengembangan materi dan media, mahasiswa menjadi buta akan teknologi dan terkesan tertinggal. 3) Untuk Peneliti: Penelitian lebih lanjut dapat dilakukan untuk mengukur tingkat hasil belajar mahasiswa dalam hubungannya dengan media pembelajaran trainer pengendali kecepatan dan softstarting motor listrik dan media pembelajaran trainer pengendali kecepatan dan soft starting motor listrik dapat dikembangkan kembali dengan tampilan yang lebih menarik dan metode yang berbeda. 


\section{Daftar Pustaka}

[1] Arsyad, A. (2011). Media Pembelajaran. Jakarta: PT Raja Grafindo Persada.

[2] Riduwan \& Sunarto. 2015. Statistikan Untuk Pendidikan, Sosial, Ekonomi, Komunikasi, Dan Bisnis. Bandung: Alfabeta

[3] Sadiman, dkk. (2014). Media Pendidikan. Jakarta: PT Rajagrafindo Persada.

[4] Setyowati, dkk. 2016. Penggunaan Alat Peraga Untuk Meningkatkan Hasil Belajar Dan Keaktifan Siswa Pada Materi Peluang. Jurnal Matematika Kreatif-Inovatif. 7 (1) 2430. (http//journal.unnes.ac.id, diunduh 25 juli 2017)

[5] Sugiyono. (2015). Metode Penelitian Pendidikan Pendekatan Kuantitatif, Kualitatif, dan $R \& D$. Bandung: Alfabeta

[6] Sugiyono. (2016). Metode Penelitian Kuantitatif, Kualitatif, dan R\&D. Bandung: Alfabeta

[7] Undang-undang Republik Indonesia No 20 Tahun 2003 Tentang Sistem Pendidikan Nasional. 